\title{
What Conceptions do Greek School Students Form about Biological Evolution?
}

\author{
Lucia Prinou • Lia Halkia • Constantine Skordoulis
}

Published online: 3 June 2008

(C) Springer Science + Business Media, LLC 2008

\begin{abstract}
In Greece, since 2000, the teaching of evolutionary theory is restricted solely to lower (junior) high school and specifically to ninth grade. Even though the theory of evolution is included to the 12th grade biology textbook, it is not taught in Greek upper (senior) high schools. This study presents research conducted on the conceptions of Greek students regarding issues set out in the theory of evolution after the formal completion of the teaching of the theory. The sample comprised 411 10th grade students from 12 different schools. The research results show that the students appear to have a positive view of the idea of evolution, the evolution of man, and the common origin of organisms. However, they have retained many alternative views, or else they are completely in ignorance of basic issues in evolutionary theory regarding: what is considered evolution in biology, the main mechanism of evolutionary changes in what is considered natural selection, what the theory of evolution actually explains, and what the word theory means in science. At least in Greece, these views still prevail because the theory of evolution is marginalized in the teaching of biology in Greek schools, and biology education does not help students formulate overall conceptual structures to enable them to understand the question of biological change.
\end{abstract}

Keywords Biology teaching - Evolution education . Students' conceptions

L. Prinou $(\bowtie) \cdot$ L. Halkia $\cdot$ C. Skordoulis

Laboratory of Epistemology \& Science Education, Department of Education, National and Kapodistrian University of Athens, Athens, Greece

e-mail: lprinou@primedu.uoa.gr

\section{Introduction}

Readers of the journal Evolution: Education and Outreach may know that national science academies of 67 countries that belong to the network IAP (Inter Academy Panel-a global network of science academies) cosigned a proclamation encouraging the public, teachers, and parents to provide school pupils with instruction in evolution (IAP 2006). However, what is not exactly known and which is interesting is what actually occurs in the various countries and for what reasons. Among the national science academies which cosigned the abovementioned proclamation was the Greek Academy, the Academy of Athens. As in other countries, there are also problems in Greece with the teaching of the theory of evolution. In this article, we wanted to make a contribution to the exchange of information and research experience in what is occurring in various countries in the world with regard to the teaching of evolution.

Naturally, we are already apprised of a number of published articles referring to the manner and conditions in which evolution is taught in the USA (Moore 1998-1999, 2000; Lerner 2000; Good 2003). Also useful are studies of the way evolution is presented in the American school curriculum and textbooks, such as Skoog $(1984,2005)$, Rosenthal (1985), and Swarts et al. (1994). Other information on the teaching of evolution in the USA is included in studies of teachers' stance and other factors related to opposition to evolution, that is, creationism in the USA (Tatina 1989; Zimmerman 1991; Shankar and Skoog 1993; Osif 1997; Aguillard 1999; Meadows et al. 2000; Rutledge and Warden 2000; Rutledge and Mitchell 2002; Moore 2004; Griffith and Brem 2004; Trani 2004). Nevertheless, there are fewer articles on the situation in other countries than in the USA. Recently, in the first issue of the journal Evolution: Education and Outreach, there were two enlight- 
ening references to creationism in Germany (Kutschera 2008) and the creationist teaching in science at schools in the UK (Williams 2008). Also informative was an article on the views of Scottish biology students regarding the teaching of evolution (Downie and Barron 2000). In Spain, Barberá et al. (1999), in a survey of the Spanish biology curriculum during the twentieth century, refer among other things to pressure exerted by various social groups in the past aimed at influencing the curricula in such a way as to restrict the teaching of evolution. Moreover, Swarts et al. (1994) in their comparison of American, Chinese, and Soviet biology textbooks found that while textbooks in the USSR did have an emphasis on evolution, they neglected other issues. In comparison, Chinese textbooks introduced a far smaller number of issues, while American textbooks presented a large variety of evolutionary issues.

In Greece, since 2000, the teaching of evolutionary theory is restricted solely to lower high school (or junior high school, i.e., from grades 7 to 9) and specifically in the ninth grade. It is the final chapter in the ninth grade biology textbook.

The theory of evolution is not taught at all in upper high school (or senior high school, i.e., from grades 10 to 12); the theory is included only in the 12th grade biology curriculum. Although a chapter on evolution, the final chapter, is included in the 12th grade biology textbook, it is not taught to Greek students. That is due to the fact that what is taught or not taught in the 12th grade does not depend on what is in the school textbook but on what the schools' central administration decides to be the material on which the students are to be examined in the general examinations at the end of the school year for the 12th grade. For reasons that have never been explained, after 2000, according to a ruling issued every year, setting out the material on which students are to be examined, the chapter titled "Evolution" is excluded and therefore not taught. In effect, that means that the theory of evolution is not seen as an important chapter on which students should be examined for entry to university. Therefore, even though the theory of evolution is included in the textbook and the famous title of the article by Dobzhansky (1973), "Nothing in biology makes sense except in the light of evolution," is found on the title page of the chapter on evolution in the 12th grade biology textbook, it is not taught in Greek upper high schools. Therefore, students graduate without having been taught evolutionary theory in upper high school at all. We have written about this problem and talked about it in the press, as for example in the article, "The theory of evolution in Greek schools" in the English edition of a Greek newspaper (the daily newspaper Kathimerini) issued with the International Herald Tribune (February 11-12, 2006).

As for the existence of evolutionary concepts in the curriculum and textbooks of classes below ninth grade, (as shown in the study by Prinou et al. 2007), this is restricted and fragmentary. In the textbooks there are some isolated references to concepts such as the "adaptation" of organisms but they are given very cursory treatment. Overall, the evolutionary approach to the examination of organisms is generally absent.

Under such circumstances, it was very interesting to observe what Greek school pupils think about issues dealt with in evolutionary theory. This article therefore presents the conceptions formulated by pupils in secondary education in Greece, after the formal completion of the teaching of evolutionary theory.

\section{Methodology}

The research instrument used was a questionnaire consisting of open-ended questions and multiple choice questions. The latter offered four possible responses "Absolutely agree," "Probably agree," "Absolutely disagree," "Probably disagree," as well as "Don't know, no reply."

Regarding the selection of issues to be investigated, as well as the choice and combination of questions, reference was made to the relevant bibliography on evolution as well as other research into views and difficulties with the issues and concepts of evolutionary theory (Lucas 1971; Clough and Wood-Robinson 1985; Halldén 1988; Brumby 1979, 1984; Bishop and Anderson 1990; Rutledge and Warden 2000). The students were not told at the beginning that the questionnaire concerned the theory of evolution, and the open-ended questions were presented first.

At the end of the questionnaire, the students were asked to evaluate whether they had been taught about evolution in previous grades on a scale of 1 (=not at all), 2, 3, and 4 (=very much) and whether they had understood the theory of evolution on the same scale of 1 (=not at all) to 4 (=very much).

The sample comprised 411 students $(52.9 \%$ girls, $47.1 \%$ boys) from 12 different schools in Attica and the provinces. They were taken from the tenth grade, since the ninth grade is the last grade in which Greek school students are taught evolutionary theory, as referred to above.

The SPSS statistical program (SPSS version 13) and content analysis were used to process the questionnaire replies.

\section{Results}

On Evolution

A large percentage of students appear to generally accept the concept of evolution, as indicated by their replies:

- $77.6 \%$ of students were aware that "The species living today are the result of evolutionary processes that have 
been occurring for millions of years $11.7 \%$ were not aware of that, and $10.7 \%$ responded with "Don't know/ No reply."

- $89.3 \%$ disagreed with the statement: "All organisms appeared at the same time." Just $5.4 \%$ of students agreed and as many responded with "Don't know/No reply."

- $86.2 \%$ disagreed with the statement "Millions of years ago there were exactly the same species of plants and animals as those living today." Just $8.8 \%$ absolutely agreed, and $5.1 \%$ responded with "Don't know/No reply."

- $63 \%$ of students disagreed with the statement: "No species of animal that has lived on earth had become extinct by the time man appeared"; $18 \%$ agree, and 19\% responded with "Don't know/No reply."

\section{On the Origin of Man}

For the origin of man, $58.6 \%$ accepted that "Man has evolved from 'lower' forms of life." However, $21.9 \%$ of students do not accept that, and $19.5 \%$ responded with "Don’t know/No reply."

\section{On the Common Origin of Organisms}

For the common origin of organisms, $53.3 \%$ of students accepted the view that "All species of organisms are descended from a common ancestor in the distant past." This view is not accepted by $30.4 \%$, while $18.7 \%$ responded with "Don't know/No reply."

\section{On the Coexistence of Humans and Dinosaurs}

For the coexistence of humans and dinosaurs, $46.7 \%$ of students disagreed with the phrase: "At one time, people co-existed with dinosaurs"; $34.5 \%$ thought they had, and $18.7 \%$ responded with "Don't know/No reply."

\section{"Theory: Since There is No Evidence"}

Only $24.1 \%$ of students disagreed with the phrase: "Evolution is called a theory because there is no evidence for it"; $42.1 \%$ agreed with this view, and 33.8\% responded with "Don't know/No reply."

\section{"How Did Life on Earth Begin?"}

Only $13.2 \%$ of students do not accept that "Evolution is a theory that explains how life began on earth"; $69.6 \%$ agree that "evolution is a theory that explains how life began on earth," and 17.3\% responded with "Don't know/No reply."
The correlation of students' replies as to the extent to which evolution was taught in previous classes and how they deal with the concept that "evolution is a theory that explains how life began on earth" proved to be statistically significant with $\chi^{2}=17.687, \mathrm{BE}=6$, and $p$ value $0.007<$ 0.05 and showed that only $9.7 \%$ and $6.8 \%$ of the students who evaluated their lessons in evolution correspondingly with 4 (very much) and 3 disagreed that "evolution is a theory that explains how life began on earth."

How Do Students Believe that Changes Occur? Do They Think of Using Natural Selection in Order to Explain Them?

The students were asked to decide which explanation they would give to the following questions:

\section{First Open-ended Question}

"On the news it is announced that: 'When insecticides were first sold they were very effective in eliminating flies and mosquitoes. Today, nearly 30 years later, insecticides are much less effective.' How would you explain that?"1

The following answers were given:

A large percentage of students in the sample (41.4\%) believe that organisms, in this case insects, being subjected to an environmental factor, in this case insecticide, "reacted"-all together-acquiring a new quality, e.g., immunity, antibodies, defense, protective measures, etc.

Some of the students $(20.2 \%)$ believe that the organisms were "transformed" from nonresistant to resistant because they "became accustomed, adapted, got used to... mutated... etc."

Others (3.4\%) treated the organisms in an anthropocentric manner. For example: "The insects learn to... know..., feeling threatened, find ways to protect themselves."

Yet others $(15.6 \%)$ cited other reasons, e.g., that "insecticides are less effective (e.g. in the interests of the manufacturers, or in order to be less harmful to people, etc."

Of the students, $19.4 \%$ gave answers that reiterated the question or did not reply at all.

\section{Second Open-ended Question}

"On an island subjected continually to strong winds, there is a species of insects that are wingless - that is to say having small to atrophied wings, not suitable for flight. That feature helps them not to be carried away by the winds into the sea, where they would drown. Can you give an

\footnotetext{
${ }^{1}$ A similar question which was first found in Brumby's $(1979,1984)$ research, but it is also referred in contemporary textbooks.
} 
explanation as to how that species of insect came to live on the island?"

The following answers were given:

The students believe that all organisms, taken as a unified whole of almost identical individuals, have changed or been transformed to acquire a feature that enables them to live in the specific environment, either because

- Their bodies were formed in accordance with the requirements for survival in their environment, it "happened" naturally..., were created in that way so as to... etc. $(27.6 \%)$

- Or because the insects adapted to their environment to..., they evolved to adapt, etc. (22.1\%)

- Or that "their wings atrophied because they stopped using them, etc." (9.5\%)

A small percentage $(7.4 \%)$ of students replied that "the insects were born like that - there were also insects with wings but they died out..." while a considerable percentage $(33.3 \%)$ reiterated the phrasing of the question, did not reply at all, or did not know, etc.

New Characteristics and the Invocation of the Concept of "Need"

In addition, the majority of students believed that new features emerged in the organisms out of need: $59.3 \%$ agreed that "new features appear in organisms because they need them in order to survive," while $24.1 \%$ did not know or did not reply. Only $16.6 \%$ did not accept this view.

A correlation of the answers in the open question $\left(a_{1}\right)$, "organisms' bodies were formed in accordance with the need to survive," or that $\left(\mathrm{a}_{2}\right)$ "organisms adapt themselves according to their environment" and (b) the view that "new features appear in organisms because they need them..." proved to be statistically significant with $\chi^{2}=15.953, \mathrm{BE}=$ 8 , and $p$ value $0.043<0$. 05 and showed that:

A large percentage of students $\left(a_{1}\right), 62.3 \%$ of those who believe that "the bodies of organisms were formed in accordance with the need to survive" and $\left(a_{2}\right), 70.3 \%$ of those who believe that "insects adapt to their environment," that is, those who did not reply in a scientific manner to the open-ended question, believe that "new features appear in organisms because they need them in order to survive."

\section{What is "Chosen" in Natural Selection?}

The students have a completely different perception than the scientific view as to how natural selection operates. They take the simplistic view that natural selection is the process in which stronger individuals are favored. Only $23.6 \%$ disagreed with the view that "in the struggle for survival natural selection favors the stronger individuals."
Sixty-three percent of the students accepted that view, and $13.4 \%$ either said they did not know or else they did not reply.

Evolution refers to changes in populations_-not individuals

Finally, the students believed that biological evolution refers to changes in individuals, not populations. Only $26.8 \%$ of students were aware that "evolution refers to changes in populations - not individuals"; $46.7 \%$ disagreed with this claim, and a considerable percentage of $26.5 \%$ either did not know or did not reply.

- The correlation of students' replies (a) as to "to what extent they had been taught evolution in previous classes" and (b) the view that "evolution refers to changes in populations, not individuals" proved to be statistically significant with $\chi^{2}=26.720, \mathrm{BE}=6$, and $p$ value $0.000<0.05$ and showed that:

- $71 \%$ of the students in the sample who evaluated their previous lessons in evolution with 4 (=very much) and about half - $49.6 \%$ - of the students in the sample who evaluated their lessons in evolution with 3 disagreed with the scientific view. That is, they believe that evolution concerns changes in individuals; they do not know that evolution refers to changes in populations.

- The correlation of students' replies in the sample (a) as to "how far they have understood the theory of evolution" and (b) how they deal with the view that "evolution refers to changes in populations and not individuals" proved statistically significant with $\chi^{2}=$ $29.545,6$, and $p$ value $0.000<0.05$ and showed that:

- Only $32.3 \%$ of the students in the sample who evaluated their understanding of the theory of evolution with 4 (=very well) agreed with the scientific view.

\section{Comments and Conclusions}

The following are comments derived from the study:

1. As indicated by their answers, the students appear to be favorably disposed toward the concept of evolution. Furthermore, a rather large percentage of students (about 60\%) show they accept that man has evolved from lower forms of life. Over half the students accept the common origin of organisms. However, at the same time, it appears that students think that "biological evolution" is the same as a development, a progress, that is, a change in the individuals themselves and not "changes in the synthesis of populations," as it is considered to be in biology. That could be related to the meaning of the word "evolution" (exelixis) in the Greek language, where it is primarily used to describe the 
progress made by individuals and/or an improvement in their condition.

2. When evolution is called a theory, then the students (42.1\%) believe that it is not backed up by evidence. That is also related to the fact that in the Greek language, the word "theory" is often used in the sense of a "conjecture" and also incorporates the element of improvisation. Students are not at all familiar with the scientific meaning of the word "theory." That is why whenever the word theory comes up, it raises doubt and uncertainty with regard to what it is defining. A considerable number of students (34\%) chose the reply "Don't know-No answer" on this point.

3. The positive answers given by Greek students regarding the coexistence of humans and dinosaurs are a consequence of their ignorance of the history of life on earth.

4. Our research found a widespread view that the theory of evolution explains the genesis (origin) of life on earth. Typically, a very low percentage of students $(10 \%)$ who think they have been taught evolutionary theory "very much" do not link the two subjects.

5. Overall, the students do not use natural selection to explain changes in organisms and their answers reveal a total ignorance of the means with which these occur. They treat organisms as a unified total of almost identical individuals that change at the same time due to need and use the schemas of transmutationism and transformationism as do the advocates of the corresponding theories of evolution (Mayr 2001) who do not use population thinking. These schemas based on essentialistic thinking are used even today because population thinking has not been encouraged.

Throughout their biology education, the students are not familiarized with the concept of intraspecies variation. Therefore, it is not easy for them to apply a model of selection on a totality of individuals whom they have been accustomed to viewing as similar, that is, a totality of individuals consisting of almost identical individuals.

Due to the fact that they are not at all familiar with the concept of intraspecies variation, they believe that the appearance of new "suitable" features happens to facilitate the organisms, whenever a need arises. That is, their reasoning schema is reversed.

In Conclusion The research results show that the students appear to have a positive view of the idea of evolution, the evolution of man, and the common origin of organisms. However, they have retained many alternative views, or else they are completely in ignorance of basic issues in evolutionary theory regarding: (a) what is considered evolution in biology, (b) the main mechanism of evolutionary changes in what is considered in biology as natural selection, (c) what the theory of evolution actually explains, and (d) what the word theory means in science.

At least in Greece, these views still prevail because the theory of evolution is marginalized in the teaching of biology in Greek schools and the evolutionary view of organisms does not pervade the entirety of biology teaching.

Students' biology education does not help them formulate overall conceptual structures to enable them to understand the question of biological change, so they are left to draw their own conclusions or are forced to use pprims (phenomenological primitives), such as the concept of need (Southerland et al. 2001).

Moreover, because the teaching of evolutionary theory is marginalized, not even teachers who want to teach evolution (this only happens in junior high school as referred to above) are equipped to deal with students' alternative views - some of which they themselves sharenor have they ever had the opportunity to discuss the problems they face (Prinou et al. 2005).

The way things are now in Greek schools is that students are condemned, without their knowledge, to ignorance of a scientific theory that is of such importance to biology.

Passing over the teaching of the evolutionary theory, for whatever reason, is unjustifiable.

Possible reasons could be historical reasons such as the tight bond between the Orthodox Church and state, along with the antievolutionary polemic from Church circles or from various Christian organizations (analytically in Prinou et al. 2008).

For if factors that fight its teaching are perpetuating a tradition inherited from the past out of fear that students' religious faith will be shaken, reliable research (Bishop and Anderson 1990; Demastes et al. 1995) has shown that students' understanding of evolutionary theory and their ability to use it can be improved without affecting their beliefs.

In jest, one could say that the opposition on the part of those who have restricted the teaching of evolution in different parts of the world generally and in Greek schools particularly recalls the Englishwoman who, when informed of Darwin's theory, cried: "We have descended from the apes! Let's hope it isn't true. But if it is, let us pray that people won't hear about it!" (Blan 1995, p.17 in the Greek edition).

\section{References}

Aguillard D. Evolution education in Louisiana public schools: a decade following Edwards v Aguillard. Am Biol Teach 1999;61 (3): 182-8.

Barberá O, Beatriz Z, Pérez-Pla JF. Biology curriculum in twentiethcentury Spain. Sci Educ 1999;83:97-111. 
Bishop B, Anderson C. Student conceptions of natural selection and its role in evolution. J Res Sci Teach 1990;27:415-27.

Blan M. Les heritiers de Darwin - L' evolution en mutation. Athens: Stahy; 1995. (Greek edition).

Brumby MN. Problems in learning the concept of natural selection. J Biol Educ 1979;13:119-22.

Brumby MN. Misconceptions about the concept of natural selection by medical biology students. Sci Educ 1984;68:493-503.

Clough EE, Wood-Robinson C. How secondary students interpret instances of biological adaptation. J Biol Educ 1985;19:125-30.

Demastes SS, Good RG, Peebles P. Students' conceptual ecologies and the process of conceptual change in evolution. Sci Educ 1995;79(6):637-66.

Dobzhansky T. Nothing in biology makes sense except in the light of evolution. Am Biol Teach 1973;35(3):125-9.

Downie JR, Barron NJ. Evolution and religion: attitudes of Scottish first year biology and medical students to the teaching of evolutionary biology. J Biol Educ 2000;34(3):139-46.

Good R. Evolution and creationism: one long argument. Am Biol Teach 2003;65(7):512-6.

Griffith AJ, Brem KS. Teaching evolutionary biology: pressures, stress, and coping. J Res Sci Teach 2004;0(0):1-19.

Halldén $\mathrm{O}$. The evolution of species: pupils' perspectives and school perspectives. Int J Sci Educ 1988;10:541-52.

IAP, The Interacademy Panel On International Issues homepage; 2006. Available at: http://www.interacademies.net/.

Kutschera U. Creationism in Germany and its Possible Cause. Evol Educ Outreach 2008;1:84-6.

Lerner LS. Good science, bad science: teaching evolution in the States. Washington DC: Thomas B. Fordham Foundation; 2000.

Lucas A. The teaching of adaptation. J Biol Educ 1971;5:86-90.

Mayr E. What evolution is. New York: Basic; 2001.

Meadows L, Doster E, Jackson FD. Managing the conflict between evolution \& religion. Am Biol Teach 2000;62(2):102-7.

Moore R. Creationism in the United States A-VII. Am Biol Teach, 60(79)-61(1-4); 1998-1999 (September-December and January-May).

Moore R. The revival of creationism in the United States. J Biol Educ 2000;35(1):17-21.

Moore R. When a biology teacher refuses to teach evolution: a talk with Rod LeVake. Am Biol Teach 2004;66(4):246-50.

Osif AB. Evolution \& religious beliefs: a survey of Pennsylvania high school teachers. Am Biol Teach 1997;59(9):552-6.
Prinou L, Halkia L, Skordoulis C. Teaching the theory of evolution: secondary teachers' attitudes, views and difficulties; 2005. Available at: http://www.ihpst2005.leeds.ac.uk/papers/Prinou_ Halkia_Skordoulis.pdf.

Prinou L, Halkia L, Skordoulis C. The evolutionary theory in the Greek life sciences primary and secondary textbooks from the beginning of the 20th century to date. In Proceedings IOSTE International Meeting: critical analysis of school science textbooks, Tunisia; 2007a.

Prinou L, Halkia L, Skordoulis C. The reception of the theory of evolution in Greek education; 2008 (in press).

Rosenthal DB. Social issues in high school biology textbooks: 19631983. J Res Sci Teach 1985;21:819-31.

Rutledge ML, Mitchell MA. High school biology teacher' knowledge structures, acceptance and teaching of evolution. Am Biol Teach 2002;64(1):21-8.

Rutledge ML, Warden AM. Evolutionary theory, the nature of science \& high school biology teachers: critical relationships. Am Biol Teach 2000;62(1):23-31.

Shankar GG, Skoog GD. Emphasis given evolution and creationism by Texas high school biology teachers. Sci Educ 1993;77 (2):221-33.

Skoog G. The coverage of evolution in high school biology textbooks published in the 1980s. Sci Educ 1984;68(2):117-28.

Skoog G. The coverage of human evolution in high school biology textbooks in the 20th century and in current state science standards. Sci Educ 2005;14:395-422.

Southerland SA, Abrams E, Cummins C, Anzelmo J. Understanding students' explanations of biological phenomena: conceptual frameworks or P-prims? Sci Educ 2001;85:328-48.

Swarts FA, Anderson OR, Swetz FJ. Evolution in secondary high school Biology textbooks of the People's Republic of China, United States of America and the latter stages of the Union of Soviet Socialist Republics. J Res Sci Teach 1994;31(5):475-505.

Tatina R. South Dakota high school biology teachers and the teaching of evolution and creationism. Am Biol Teach 1989;51(5):275-80.

Trani R. I won't teach evolution; it's against my religion. Am Biol Teach 2004;66(6):419-27.

Williams JD. Creationist teaching in school science: a UK perspective. Evol Educ Outreach 2008;1:87-95.

Zimmerman M. The evolution-creation controversy: opinions of Ohio school board presidents. Sci Educ 1991;75(2):201-14. 